\title{
Corporate Governance Policies in Indian commercial Banks: An Empirical Analysis
}

\author{
Mohi-ud-Din Sangmi ${ }^{1}$, Sumaira Jan $^{2}$ \\ ${ }^{1}$ (Professor, Department of Business and Financial Studies, University of Kashmir, Srinagar, India) \\ ${ }_{2}^{2}$ (Research Scholar, Department of Business and Financial Studies, University of Kashmir, Srinagar, India)
}

\begin{abstract}
Sound Corporate Governance Policies are important to the creation of shareholders value and maintaining the confidence of customers and investors alike. The Bank's Corporate Governance Policies are designed to ensure the independence of the Board of Directors (BoDs) and its ability to effectively supervise management's operation of the Bank. This paper examines the Corporate Governance Policies of Commercial banks in India which are classified into Public Sector Banks and Private Sector Banks. Private Sector banks are further classified into Old Private Sector Banks and New Private Sector Banks in the study. The Governance Policies have been assessed with the help of five parameters namely, Reasons for the written code of Corporate Governance, Availability of Corporate Governance Policies, Distribution of Related Material to concerned parties, Issues in Code of conduct and Other components of Corporate Governance. Moreover, the study empirically tests the difference in the Corporate Governance Policies between the Public Sector banks and Private Sectors banks; and, also between the Old Private Sector Banks and New Private Sector Banks in India.
\end{abstract}

Keywords: Corporate Governance (C.G.), Board of Directors (BoDs), Code of Conduct, Public Sector Banks and Private Sector Banks, Clause 49 of the Securities and Exchange Board of India (SEBI).

\section{Introduction}

As corporations operate and compete in virtually all parts of the world, there has always been a need to develop some governing law and the purpose of that law has been to integrate the legislatively imposed standards with the realities of the market place, so that overall goals would be promoted. However, the series of corporate failures such as Enron and WorldCom have brought corporate governance into the limelight. These companies collapsed because of the corporate mis-governance and unethical practices they indulged in. Satyam scandal in India is also the case of corporate mis-governance. Satyam case exposed the complete lack of accountability in the company and raised questions on corporate governance practices of the country's listed entities.

Corporate Governance against the backdrop of globalization has become a delicate and onerous task for survival as well as for seizing the opportunities. Corporate governance stipulates parameters of accountability, control and reporting functions of the board of directors of the corporations. According to the Organization for Economic Cooperation and Development (OECD), "corporate governance is a set of relationships between a company's management, its Board, its shareholders, and other stakeholders. Corporate governance provides the structure through which the objectives of the company are set, and the means of attaining those objectives and monitoring performance are determined. Corporate governance should also provide proper incentives for the Board and management to pursue objectives that are in the interests of the company and shareholders and should facilitate effective monitoring, thereby encouraging firms to use resources more efficiently."

From a financial industry perspective, corporate governance involves the manner in which the business affairs of individual institutions are governed by their Boards and management. It also includes the effective management of compliance with applicable laws, regulations, and guidelines. The focus on corporate governance is particularly acute in financial services and, most of all, in the banking sector. Governance in banks is a considerably more complex issue than in other sectors. Banks will attempt to comply with the same codes of board governance as other companies but, in addition, factors like risk management, capital adequacy and funding, internal control, and compliance, all have an impact on their matrix of governance. Governance is also a curiously two-sided issue for banks since their funding and, often, ownership of other companies makes them a significant stakeholder in their own right. In the financial system, corporate governance is not only vital at the individual company level, but it also is a critical element in maintaining a sound financial system and a robust economy, Romero (2003). 


\section{Literature Review}

According to Cocris \& Ungureanu (2007) banks are special and their corporate governance systems are of major importance because banks have a critical position in the development of economies due to their major role in running the financial system. The banking industry is unique because it is simultaneously consolidating and diversifying. There is a significant public dimension to the banking firms; bank managers function in the light of two distinct sets of interests: one is the private interest, internal to the firm, and the other is the public interest, external to the firm. This study emphasizes the implications of banks' specific attributes on their corporate governance framework viz. greater opaqueness and greater regulation from the point of view of current economic framework and further it analyses the environment with increased regulation of the banking firm, as a governance control mechanism. The authors report that sound corporate governance system of banks increases the efficiency of firms and also enhances the credibility of the banking industry, which has positive economic effects and countries that adopt regulation on forcing the disclosure of accurate, comparable information about banks tend to have better developed banks. These policies enhance the operations and governance of banks. The authors opine that banks, nowadays, respond to tight regulation through mechanisms such as financial innovation, securitization, globalization and new technologies, if these responses are managed adequately, they may have stimulating effects on the governance of banks. (Levine, 2004), discusses two special attributes of banks that make them special in practice: greater opaqueness than other industries and greater government regulation. These attributes weaken many traditional governance mechanisms. Next, the study reviews emerging evidence on which government policies enhance the governance of banks and draws tentative policy lessons. In sum, he concludes that the existing work suggests that it is important to strengthen the ability and incentives of private investors to exert governance over banks rather than relying excessively on government regulators.

Arun and Turner (2004) discuss the corporate governance of banking institutions in developing economies. Based on a theoretical discussion of the corporate governance of banks, authors suggest that banking reforms can only be fully implemented once a prudential regulatory system is in place. An integral part of banking reforms in developing economies is the privatization of banks; so the corporate governance reforms may be a prerequisite for the successful divestiture of government ownership. Furthermore, authors opine that the increased competition resulting from the entrance of foreign banks may improve the corporate governance of developing-economy banks. Chahine and Safieddine (2009) provide new insights into the effect of corporate governance in emerging markets by examining the banking system in Lebanon. This research shows that board characteristics influence bank conduct and performance. Using a sample of 749 firm years of unbalanced panel data on the banking industry in Lebanon from 1992 to 2006, this paper shows that bank performance, as measured by Return on Assets and the Return on Equity, have a positive association with board size. It also identifies a quadratic relationship between bank performance and board independence as both Return-on-Assets and Return-on-Equity first decrease and then increase in direct proportion to the increased percentage of outside directors on the board. This study sheds some light on the differential impact of corporate governance on firm performance across industries and countries. It concentrates on banks in developing countries that are generally known to suffer from high asymmetric information and where concerns about safety and soundness remain. Hence, it contributes to the existing debate on appropriate regulations for an effective and stable financial system in the Arab World. Also, it complements the Basel Committee standards for bank supervision and capital adequacy reinforcement, and offers regulators some evidence on the relationship between board size and bank performance in a developing country such as Lebanon. Asian roundtable on corporate governance (2006) identifies corporate governance that affects Asian banks and finds that banking sector in many Asian jurisdictions do not have, in place, sufficient institutional infrastructure necessary for effective enforcement of the corporate governance of the corporate policy framework. The members of the Task Force believe that Asian banks play a dominant role in regional finance due to the immature capital markets, and Asian policy makers should be aware that sound corporate governance of banks cannot be developed effectively without tackling institutional constraints and weaknesses. The Task Force recommends that Asian banking supervisors should take the lead to improve corporate governance of banks in Asia. They believe that banking supervisors in all Asian Jurisdictions, in conjunction with securities regulators and stock exchanges, should develop national codes of corporate governance of banks, a template on which banks should base the development of their own codes respectively, based in turn on the conditions of each jurisdiction and on existing corporate governance codes. Furthermore, banking supervisors should develop rating mechanisms for corporate governance of banks so that banks can improve their corporate governance framework time and again.

Pati (2006) explains that policy framework for corporate governance has been developed lately in India and for banking it is still evolving. For Indian banking the RBI has taken the sole responsibility of framing policy in this regard. The Standing Committee on International Financial Standards and Codes which was set up in 1999 to bring common financial standards in line with international practices constituted an advisory committee on corporate governance under the chairmanship of R.H. Patil. The sub-committee submitted its 
report in 2001; and in this report it has been observed that since most of the Indian companies belong to the "insider" model of East Asia i.e. dominance of family/promoter ownership and control, it is essential to bring quick reforms in corporates/banks/financial institutions/public sector enterprises to make them more autonomous and professional. The Group looked into public sector banks and noted that the first important step to improve governance mechanism in these units is to transfer the actual governance functions from the concerned administrative ministries to the board and also strengthen them by streamlining the appointment process of directors. Furthermore, as a part of strengthening the functioning of their boards, banks should appoint a risk management committee of the board in addition to the three other board committees viz., audit, remuneration and appointment committees. Further, the RBI constituted a Consultative Group of Directors of Banks and Financial Institutions under the Chairmanship of Dr. A.S. Ganguly to review the supervisory role of boards of banks and FIs. This group looked into the functioning of the Boards vis-à-vis compliance, transparency, disclosures, audit committees and suggested measures for making the role of the Board of Directors more effective. The other steps taken by RBI in respect of corporate governance in the Indian Banking System are classified into three categories viz., a) Transparency b) Off-site surveillance and c) Prompt corrective action. The author surveys that the post implementation scenario of corporate governance policies in Indian banking has brought mixed outcomes. Along with qualitative changes in disclosure practices most of the banks have shown handsome profit and low NPAs. Statistically significant correlations of governance with important financial variables on expected lines have been found for banking in India.

After reviewing the available literature and understanding the complexity of corporate Governance in banks, it has been observed that no detailed study has been done to analyze the Corporate Governance Policies in the banking sector in India in the light of various committees' recommendations which were appointed in India in the recent decade. Thus, there arises a need to make an in-depth analysis of Corporate Governance Policies of the commercial banks operating in India.

\section{Research Objectives}

The research aims at studying the following attributes of Corporate Governance Policies in Indian Commercial banks: -

1. To study the reasons for the written code of Corporate Governance in the Indian commercial banks;

2. To assess the availability of corporate Governance policies in the select commercial banks of the India;

3. To review the distribution of related material of corporate Governance viz. code of conduct/ethics in the sample commercial banks of India;

4. To study the various issues taken into account in the code of conduct for the corporate Governance of Indian commercial banks; and

5. To offer suggestions, on the basis of study results, regarding the improvement of Corporate Governance policies in the Indian commercial banks.

\section{Hypotheses Of The Study}

1. $\mathbf{H}_{\mathbf{0}}$ : There is no significant difference between the Corporate Governance Policies of Public Sector Banks and Private Sector Banks in India.

$\mathbf{H}_{\mathbf{1}}$ : There is significant difference between the Corporate Governance Policies of Public Sector Banks and Private Sector Banks in India.

2. $\mathbf{H}_{\mathbf{0}}$ : There is no significant difference between the Corporate Governance Policies of Old Private Sector Banks and New Private Sector Banks in India.

$\mathbf{H}_{1}$ : There is significant difference between the Corporate Governance Policies of Old Private Sector Banks and New Private Sector Banks in India.

\section{Data Base And Methodology}

The present study, conducted in the year 2013, is empirical in nature that examines the Corporate Governance Policies in Indian commercial banks. In order to complete the study, data has been collected from both Primary as well as secondary sources. Secondary data are based on official records, annual reports, journals and books. The primary data are collected through well designed questionnaire which has been administered to the officers and managers of the banks concerned.

\section{V.1 Questionnaire Design}

The questionnaire used for the study aims at the Corporate Governance Policies of Indian commercial banks with the help of four constructs viz., Reasons for the written code of Corporate Governance, Availability of Corporate Governance Policies, Distribution of Related Material to concerned parties, Issues in the Code of Conduct and Other Components of Corporate Governance. The questionnaire that has been used in this study was developed and used by Tandelilin, Kaaro, Mahadwartha, Supriyatna (2007). In the questionnaire, there are 
only close ended questions which are measured with the help of 5 point Likert scale with the scores ranging from $1=$ Strongly Disagree, $2=$ Disagree, $3=$ Neither Agree, Nor Disagree, $4=$ Agree and $5=$ Strongly Agree .

\section{V.2 Universe of the Study and Sample Selection}

The universe of the study consists of 96 Commercial Banks operating in India, out of which 27 are Public Sector Banks, 31 Private Sector Banks and 38 Foreign Banks. Initially, the present study aimed to study all the commercial banks (96) and accordingly 96 questionnaires were delivered to all commercial banks through email and by personally visiting them. However, out of them only 33 questionnaires were returned, representing 20 Public Sector Banks and 13 Private sector Banks. Ironically, all Foreign banks did not respond to the study on the pretext of secrecy. Thus, foreign banks have been excluded from the study. Out of the total Private Sector Banks responded, 8 are Old Private Sector Banks and 5 are new Private Sector Banks. The total response rate found in the study is $34.4 \%$.

Exhibit 1: Data Collection/ Sector-Vise Response Rate

\begin{tabular}{|c|c|c|c|c|}
\hline Questionnaires & $\begin{array}{c}\text { Public Sector } \\
\text { Banks }\end{array}$ & $\begin{array}{c}\text { Private } \\
\text { Sector Banks }\end{array}$ & $\begin{array}{c}\text { Foreign } \\
\text { Banks }\end{array}$ & Total \\
\hline Delivered & 27 & 31 & 38 & 96 \\
\hline Collected & 20 & 13 & 0 & 33 \\
\hline Response Rate & $74.07 \%$ & $41.94 \%$ & 0 & $34.4 \%$ \\
\hline
\end{tabular}

Source: Data collected in the year 2013 by the Researcher.

Thus the sample of the study includes the following: -

Public Sector Banks: - Punjab National Bank, Canara Bank, United Bank of India, Union Bank of India, Punjab and Sind Bank, Bank of India, State Bank of India, Vijaya Bank, Indian Bank, Bank of Baroda, UCO Bank, Dena Bank, State Bank of Patiala, State Bank of Travancore, State Bank of Mysore, Corporation Bank, Allahabad Bank, Oriental Bank of Commerce, Andra Bank, Syndicate Bank.

Old Private Sector Banks: - Federal Bank, Catholic Syrian Bank, Nainital Bank, Jammu \& Kashmir Bank, ING Vysya Bank, Karnataka Bank, Dhanlaxmi Bank and City Union Bank.

New Private Sector Banks: - Kotak Mahindra Bank, Yes Bank, IndusInd Bank, Axis Bank, ICICI Bank.

\section{V.3 Statistical Tools and Techniques used to analyze the data}

The assessment of Corporate Governance Practices has been done with the help of following statistical tools and techniques:
$>$ Average (Mean)
$>$ Standard Deviation
$>$ T- Test has been used for hypotheses testing

\section{Results And Discussions}

Each company has its own Governance Policies which have been evolved and adopted from time to time in view of the legal and cultural scenarios these companies are operating. In India, the Corporate Governance Policies are framed in the light of Companies Act and Clause 49 of Securities and Exchange Board of India (SEBI)'s listing agreement. Corporate Governance Policies represent the intention of banks to implement Corporate Governance. Sound Corporate Governance Policies are important to the creation of shareholders value and maintaining the confidence of customers and investors alike. The Bank's Corporate Governance Policies are designed to ensure the independence of the Board of Directors (BoDs) and its ability to effectively supervise management's operation of the Bank. This study conducted in the year 2013 uses several constructs to measure the Corporate Governance Policies of Indian commercial banks. These constructs consist of several issues regarding Corporate Governance Policies which are discussed under the following heads:

1. Reasons for the written Code of Corporate Governance

2. Availability of corporate Governance policies

3. Distribution of related material 
4. Issues in code of conduct

5. Other components of corporate Governance

\section{Reasons for the written Code of Corporate Governance}

Clause 49 of the SEBI's Listing Agreement entered into with the Stock Exchanges, requires, as part of Corporate Governance the listed entities to lay down a Code of Conduct for Directors on the Board of the entity and its Senior Management. Senior Management has been defined to include personnel who are members of its Core Management and functional heads excluding the Board of Directors. This Code of Conduct attempts to set forth the guiding principles on which the Bank shall operate and conduct its daily business with its multitudinous stakeholders, government and regulatory agencies, media, and anyone else with whom it is connected. Table 1 indicates that the banks in India have developed written code of Corporate Governance for the reasons that they wanted to clearly magnify the rights of shareholders, duties of the Board of Directors and the rules of disclosure. So far as the rights of shareholders are concerned, the Public Sector Banks strongly believe $(\bar{x}=4.85)$ that the shareholders are supreme and their rights need to be depicted clearly in the written form. Similarly, such views are also shared by the Private Sector Banks ( $\bar{x}=4.38$ ) with S.D. $=0.65$. On the same analogy, all the banks in India perceive that the duties of the Board need to be clearly delineated, as the mean value shows $\bar{x}=4.80$ and 4.68 respectively for Public Sector Banks and Private Sector Banks. Moreover, the rules of disclosure are an important component of the Corporate Governance Policies as all the banks strongly agree that these rules need to be strictly in the written form as the value of $\bar{x}=4.75$ and 4.38 respectively for the same. A further analysis of the Table 1 reveals that there is no significant difference in the views of the Old Private Sector Banks and the new Private Sector Banks as the average mean values of both are almost similar $\bar{x}=4.29$ and 4.60 respectively for Old and New Private Sector banks.

\section{Table 1: - Reasons for Written code of Corporate Governance}

\begin{tabular}{|c|c|c|c|c|c|c|c|c|c|}
\hline \multirow[b]{2}{*}{$\begin{array}{r}\text { S. } \\
\text { No } \\
\end{array}$} & \multirow[b]{2}{*}{ Elements } & \multicolumn{2}{|c|}{$\begin{array}{l}\text { Public } \\
\text { Banks } \\
(\mathbf{N}=\mathbf{2 0})\end{array}$} & \multicolumn{2}{|c|}{$\begin{array}{l}\text { Old Private } \\
\text { Sector Banks } \\
(\mathbf{N}=\mathbf{0 8})\end{array}$} & \multicolumn{2}{|c|}{$\begin{array}{l}\text { New Private } \\
\text { Sector Banks } \\
(\mathbf{N}=05)\end{array}$} & \multicolumn{2}{|c|}{$\begin{array}{l}\text { Total Private } \\
\text { Sector Banks } \\
(\mathrm{N}=13)\end{array}$} \\
\hline & & Mean & St. Dev. & Mean & St. Dev. & Mean & St. Dev. & Mean & St. Dev. \\
\hline & $\begin{array}{l}\text { The written code } \\
\text { of Corporate } \\
\text { Governance has } \\
\text { been put in place } \\
\text { because of the: }\end{array}$ & & & & & & & & \\
\hline $\bar{a}$ & $\begin{array}{l}\text { The rights of } \\
\text { shareholders }\end{array}$ & 4.850 & 0.366 & 4.250 & 0.707 & 4.600 & 0.548 & 4.385 & 0.650 \\
\hline $\mathrm{b}$ & $\begin{array}{l}\text { Duties of the } \\
\text { Boards }\end{array}$ & 4.800 & 0.410 & 4.375 & 0.744 & 4.600 & 0.548 & 4.462 & 0.660 \\
\hline $\mathrm{c}$ & $\begin{array}{l}\text { Rules } \\
\text { disclosure }\end{array}$ & 4.750 & 0.444 & 4.250 & 0.707 & 4.600 & 0.548 & 4.385 & 0.650 \\
\hline & Total: (Average) & 4.800 & 0.407 & 4.292 & 0.719 & 4.600 & 0.548 & 4.411 & 0.653 \\
\hline
\end{tabular}

Source: Survey conducted by the researcher.

Note: Scale used in the table 1 is 5 point Likert Scale with responses 1 (strongly Disagree) to 5 (strongly Agree)

\section{Availability of corporate Governance Policies}

This constructs shows that the banks' must ensure that their Corporate Governance Policies are available to regulators, employees and public at large. Table 2 reveals that so far as the at the availability of Corporate Governance Policies to regulators is concerned, both Public Sector Banks as well as Private Sector Banks strongly agree that Corporate Governance Policies should be made available to them as their mean value shows $\bar{x}=4.85$ and $\bar{x}=4.77$ respectively. Similarly, employees as being important part of the bank should also be made aware of the Corporate Governance Policies in both Public Sector Banks as well as Private Sector 
Banks with mean values $\bar{x}=4.75$ and 4.54 respectively. Moreover, such views are also shared by Public Sector Banks $(\bar{x}=4.40)$ and Private Sector Banks $(\bar{x}=4.38)$ over the availability of corporate Governance Policies to Public. By taking the overall analysis of the Table 2, all the Commercial Banks strongly agree that Corporate Governance Policies must be made available to the stakeholders as mentioned with no significant difference between the Old Private Sector Banks $(\bar{x}=4.58)$ and New Private Sector Banks $(\bar{x}=4.53)$ respectively.

\section{Distribution of Related Material to Concerned Parties}

In this construct, an attempt has been made to show that Banks distribute its code of conduct/ethics to their employees and shareholders. Table 3 show that Code of Conduct/ethics is an important component of Corporate Governance; so, both Public Sector Banks as well as Private Sector Banks strongly believe that it should be distributed to all employees, as the mean value shows $\bar{x}=4.85$ and 4.54 respectively. As far as the distribution of Code of Conduct/ethics to shareholders is concerned, Public Sector banks strongly agree that they should be made aware of it $(\bar{x}=4.60)$ and S.D $=0.75$. Similarly, Private Sector Banks also have the same opinion with mean value $\bar{x}=4.08$. A further analysis of the Table 3 reveals that there is no significant difference in the views of the Old Private Sector Banks and the New Private Sector Banks as the mean values of both are almost similar $(\bar{x}=4.25)$ and $(\bar{x}=4.40)$ respectively for the same.

\section{Table 2: -Availability of Corporate Governance Policies}

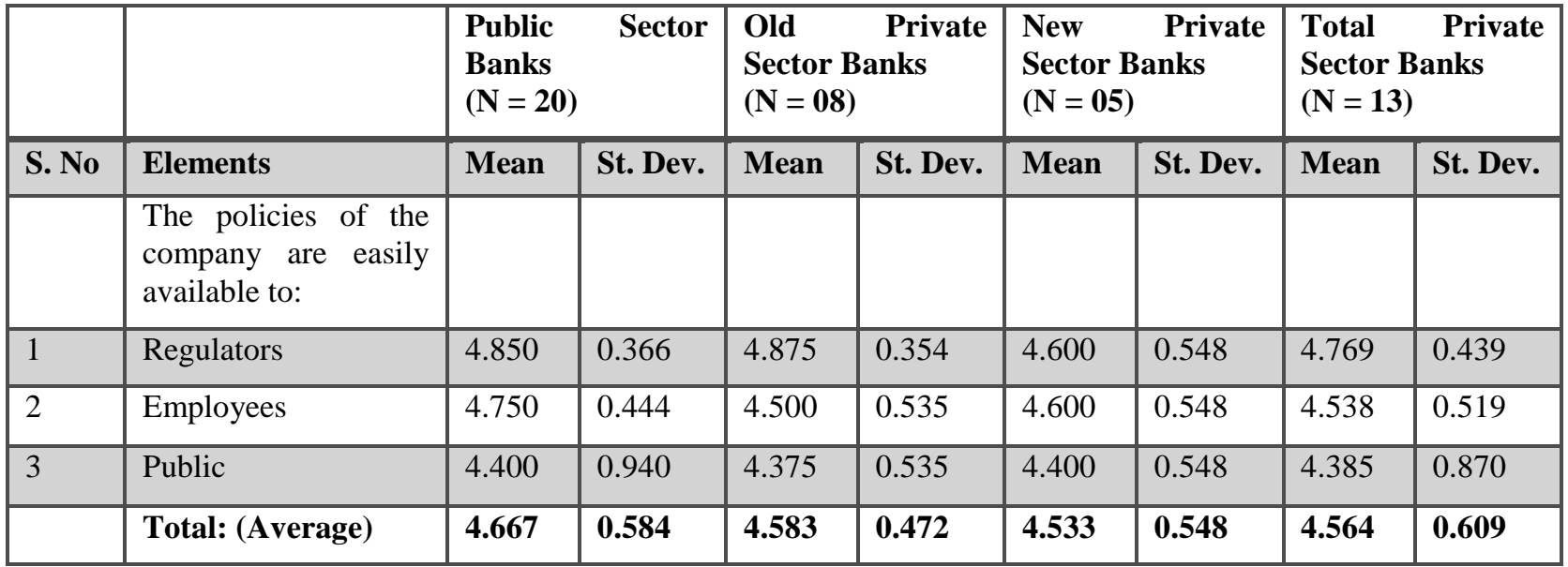

Source: Survey conducted by the researcher.

Note: Scale used in the table 2 is 5 point Likert Scale with responses 1 (strongly Disagree) to 5 (strongly Agree)

Table 3: - Distribution of Related Material to Concerned Parties

\begin{tabular}{|l|l|l|l|l|l|l|l|l|l|}
\hline & & \multicolumn{2}{|l|}{$\begin{array}{l}\text { Public Sector } \\
\text { Banks } \\
(\mathbf{N}=\mathbf{2 0})\end{array}$} & \multicolumn{2}{|l|}{$\begin{array}{l}\text { Old Private } \\
\text { Sector Banks } \\
(\mathbf{N = 0 8})\end{array}$} & \multicolumn{2}{|l|}{$\begin{array}{l}\text { New Private } \\
\text { Sector Banks } \\
(\mathbf{N = 0 5})\end{array}$} & \multicolumn{2}{|l|}{$\begin{array}{l}\text { Total Private } \\
\text { Sector Banks } \\
\text { (N = 13) }\end{array}$} \\
\hline S. No & Elements & Mean & St. Dev. & Mean & St. Dev. & Mean & St. Dev. & Mean & $\begin{array}{l}\text { St. } \\
\text { Dev. }\end{array}$ \\
\hline & $\begin{array}{l}\text { The company } \\
\text { distributes code of } \\
\text { conduct/ ethics to: }\end{array}$ & & & & & & & & \\
\hline 1. & All employees & 4.850 & 0.357 & 4.500 & 0.756 & 4.600 & 0.548 & 4.538 & 0.660 \\
\hline 2. & Shareholders & 4.600 & 0.754 & 4.000 & 1.195 & 4.200 & 0.837 & 4.077 & 1.038 \\
\hline & Total: (Average) & $\mathbf{4 . 7 2 5}$ & $\mathbf{0 . 5 5 6}$ & $\mathbf{4 . 2 5 0}$ & $\mathbf{0 . 9 7 6}$ & $\mathbf{4 . 4 0 0}$ & $\mathbf{0 . 6 9 2}$ & $\mathbf{4 . 3 0 8}$ & $\mathbf{0 . 8 4 9}$ \\
\hline
\end{tabular}

Source: Survey conducted by the researcher.

Note: Scale used in the table 3 is 5 point Likert Scale with responses 1 (strongly Disagree) to 5 (strongly Agree). 


\section{Issues in code of conduct}

Various important issues that must be included in the banks' code of conduct are reflected in this construct. Table 4 shows that Public Sector Banks as well as Private Sector Banks strongly believe $(\bar{x}=4.60)$ and $(\bar{x}=4.54)$ respectively that banks' Code of Conduct should include ethical standards in dealing with customers, vendors and other relevant parties. Moreover, Company expectations of management and employees should also be shown in the Code of conduct of banks and both Public sector Banks as well as Private Sector Banks agree on the opinion with mean values $(\bar{x}=4.40)$ and $(\bar{x}=4.54)$ respectively. Furthermore, both Public Sector Banks as well as Private Sector Banks believe that two more issues should also be reflected in the code of Conduct viz., the privacy of information about outsider companies ( $\bar{x}=4.45$ and 4.23 ) and the privacy of information about employees $(\bar{x}=3.90$ and 4.46) respectively. However, all the banks strongly believe that the most important component i.e. the importance of compliance with laws and regulations should be given an important place in the Code of Conduct, as the mean values shows $(\bar{x}=4.90)$ and $(\bar{x}=4.85)$ respectively for the same. A further analysis of the Table 4 reveals that there is no significant difference of opinion between the Old Private Sector Banks and New Private Sector Banks, as their average mean values are almost similar $(\bar{x}=$ $4.525)$ and $(\bar{x}=4.520)$ respectively for Old and New Private Sector Banks.

Table 4: - Issues in Code of Conduct

\begin{tabular}{|c|c|c|c|c|c|c|c|c|c|}
\hline \multirow[b]{2}{*}{$\begin{array}{l}\text { S. } \\
\text { No }\end{array}$} & \multirow[b]{2}{*}{ Elements } & \multicolumn{2}{|c|}{$\begin{array}{l}\text { Public Sector } \\
\text { Banks } \\
(\mathbf{N}=\mathbf{2 0})\end{array}$} & \multicolumn{2}{|c|}{$\begin{array}{l}\text { Old Private } \\
\text { Sector Banks } \\
(\mathrm{N}=\mathbf{0 8})\end{array}$} & \multicolumn{2}{|c|}{$\begin{array}{l}\text { New Private } \\
\text { Sector Banks } \\
(\mathrm{N}=05)\end{array}$} & \multicolumn{2}{|c|}{$\begin{array}{l}\text { Total Private } \\
\text { Sector Banks } \\
(\mathrm{N}=13)\end{array}$} \\
\hline & & Mean & $\begin{array}{c}\text { St. } \\
\text { Dev. }\end{array}$ & Mean & $\begin{array}{c}\text { St. } \\
\text { Dev. }\end{array}$ & Mean & $\begin{array}{c}\text { St. } \\
\text { Dev. }\end{array}$ & Mean & St. Dev. \\
\hline & $\begin{array}{l}\text { The code of conduct } \\
\text { takes into account the } \\
\text { following issues: }\end{array}$ & & & & & & & & \\
\hline 1 & $\begin{array}{l}\text { Ethical standards in } \\
\text { dealing with customers, } \\
\text { vendors and other } \\
\text { relevant parties }\end{array}$ & 4.600 & 0.821 & 4.500 & 0.535 & 4.600 & 0.548 & 4.538 & 0.519 \\
\hline 2 & $\begin{array}{l}\text { Company expectations of } \\
\text { management and } \\
\text { employees }\end{array}$ & 4.400 & 0.754 & 4.500 & 0.756 & 4.600 & 0.548 & 4.538 & 0.660 \\
\hline 3 & $\begin{array}{l}\text { The privacy of } \\
\text { information about } \\
\text { outsider companies }\end{array}$ & 4.450 & 0.759 & 4.250 & 1.165 & 4.200 & 0.837 & 4.231 & 1.013 \\
\hline 4 & $\begin{array}{l}\text { The privacy of } \\
\text { information } \\
\text { employees }\end{array}$ & 3.900 & 1.447 & 4.500 & 1.069 & 4.400 & 0.548 & 4.462 & 0.877 \\
\hline 5 & $\begin{array}{l}\text { The importance of } \\
\text { Compliance with laws } \\
\text { and regulations }\end{array}$ & 4.900 & 0.308 & 4.875 & 0.354 & 4.800 & 0.447 & 4.846 & 0.376 \\
\hline & Total: (Average) & 4.450 & 0.818 & 4.525 & 0.776 & 4.520 & 0.585 & 4.523 & 0.689 \\
\hline
\end{tabular}

Source: Survey conducted by the researcher.

Note: Scale used in the table 4 is 5 point Likert Scale with responses 1 (strongly Disagree) to 5 (strongly Agree)

\section{Other components of corporate Governance}

This section includes some of the important aspects of Corporate Governance that helps to assess the corporate governance policies of banks viz. compliance officer's competence to ensure full compliance of the company with laws and regulations, BoDs under the law, made responsible for ensuring adherence to the Code of 
Governance; the bank has revealed a code of conduct/ethics clearly and employees confirmation in writing that they have complied with the code of conduct. Table 5 exhibits that both Public sector Banks as well as Private Sector Banks $(\bar{x}=4.80)$ and $(\bar{x}=4.77)$ respectively strongly believe that banks need to ensure the compliance officer's competence so that he/she can fully ensure the banking company's compliance with laws \& regulations. On the same analogy, all banks operating in India strongly believe that BODs under the law, should be made responsible for ensuring adherence to the code of Governance $(\bar{x}=4.85)$ and $(\bar{x}=4.77)$ respectively for Public Sector Banks and Private Sector Banks. Further, all banks need to ensure that the they have revealed a Code of Conduct/ethics clearly to their stakeholders and both Public as well as Private Sector Banks shares the same opinion, as their mean values are $(\bar{x}=4.85$ and 4.69) respectively. However, all banks also agree on the opinion that employees' confirmation in writing is required in order to ensure that they have complied with the code of conduct with mean values $(\bar{x}=3.70$ and 4.15$)$ respectively for the same. Lastly, the Table 5 shows that there is no significant difference between Old Private Sector Banks and New Private Sector Banks with almost similar values $(\bar{x}=4.656$ and 4.500$)$ respectively.

\section{Table 5: - Other Components of Corporate Governance}

\begin{tabular}{|c|c|c|c|c|c|c|c|c|c|}
\hline & \multirow[b]{2}{*}{ Elements } & \multicolumn{2}{|c|}{$\begin{array}{l}\text { Public Sector } \\
\text { Banks } \\
(\mathbf{N}=\mathbf{2 0})\end{array}$} & \multicolumn{2}{|c|}{$\begin{array}{l}\text { Old Private } \\
\text { Sector Banks } \\
(\mathrm{N}=08)\end{array}$} & \multicolumn{2}{|c|}{$\begin{array}{l}\text { New Private } \\
\text { Sector Banks } \\
(\mathrm{N}=05)\end{array}$} & \multicolumn{2}{|c|}{$\begin{array}{l}\text { Total Private } \\
\text { Sector Banks } \\
(\mathbf{N}=13)\end{array}$} \\
\hline $\begin{array}{c}\text { S. } \\
\text { No }\end{array}$ & & Mean & $\begin{array}{c}\text { St. } \\
\text { Dev. }\end{array}$ & Mean & St. Dev. & Mean & $\begin{array}{c}\text { St. } \\
\text { Dev. }\end{array}$ & Mean & $\begin{array}{c}\text { St. } \\
\text { Dev. }\end{array}$ \\
\hline 1 & $\begin{array}{l}\text { Compliance Officer's } \\
\text { competence to ensure full } \\
\text { compliance of the } \\
\text { company with laws \& } \\
\text { regulations }\end{array}$ & 4.800 & 0.410 & 4.875 & 0.354 & 4.600 & 0.548 & 4.769 & 0.439 \\
\hline 2 & $\begin{array}{l}\text { BODS under the law, } \\
\text { made responsible for } \\
\text { ensuring adherence to the } \\
\text { code of Governance }\end{array}$ & 4.850 & 0.366 & 5.000 & 0.000 & 4.400 & 0.894 & 4.769 & 0.599 \\
\hline 3 & $\begin{array}{l}\text { The company has } \\
\text { revealed a code of } \\
\text { conduct/ ethics clearly }\end{array}$ & 4.850 & 0.366 & 4.750 & 0.707 & 4.600 & 0.548 & 4.692 & 0.630 \\
\hline 4 & $\begin{array}{l}\text { Employees confirmation } \\
\text { in writing that they have } \\
\text { complied with the code } \\
\text { of conduct }\end{array}$ & 3.700 & 1.081 & 4.000 & 1.414 & 4.400 & 0.894 & 4.154 & 1.214 \\
\hline & Total (Average) & 4.550 & 0.556 & 4.656 & 0.619 & 4.500 & 0.721 & 4.596 & 0.721 \\
\hline
\end{tabular}

Source: Survey conducted by the researcher.

Note: Scale used in the table 5 is 5 point Likert Scale with responses 1 (strongly Disagree) to 5 (strongly Agree)

\section{Hypothesis Testing}

1. $\mathbf{H}_{0}$ : There is no significant difference between the Corporate Governance Policies of Public Sector Banks and Private Sector Banks in India.

$\mathbf{H}_{1}$ : There is significant difference between the Corporate Governance Policies of Public Sector Banks and Private Sector Banks in India.

This hypothesis has been tested and the results are given in Tables 6 and 6(A). 


\section{Table 6: - Corporate Governance Policies}

\begin{tabular}{|c|c|c|c|c|c|c|c|}
\hline & \multirow[b]{2}{*}{ Elements } & \multicolumn{2}{|c|}{$\begin{array}{ll}\text { Public } & \text { Sector } \\
\text { Banks } & \\
(\mathbf{N}=20) & \end{array}$} & \multicolumn{2}{|c|}{$\begin{array}{ll}\text { Private } & \text { Sector } \\
\text { Banks } & \\
(\mathbf{N}=13) & \end{array}$} & \multirow[t]{2}{*}{ Palue } & \multirow[t]{2}{*}{ T-value } \\
\hline $\begin{array}{l}\text { S. } \\
\text { No. }\end{array}$ & & Mean & St. Dev. & Mean & St. Dev. & & \\
\hline 1 & Reasons for the Written Code of C.G. & 4.800 & 0.407 & 4.411 & 0.653 & 0.001 & 10.079 \\
\hline 2 & Availability of C.G. Policies & 4.667 & 0.584 & 4.564 & 0.609 & 0.593 & 0.582 \\
\hline 3 & $\begin{array}{l}\text { Distribution of Related Material to } \\
\text { Concerned Parties }\end{array}$ & 4.725 & 0.556 & 4.308 & 0.849 & 0.289 & 1.592 \\
\hline 4 & Issues in Code of Conduct & 4.450 & 0.818 & 4.523 & 0.689 & 0.713 & -0.384 \\
\hline 5 & Other components of C.G Policies & 4.550 & 0.556 & 4.596 & 0.721 & 0.892 & -0.144 \\
\hline & Total (Average) & 4.638 & 0.139 & 4.480 & 0.119 & 0.091 & 1.927 \\
\hline
\end{tabular}

Source: Survey conducted by the researcher.

\begin{tabular}{|c|l|l|l|l|l|}
\hline \multicolumn{7}{|c|}{ Table 6(A): - Independent Samples Test } \\
\hline \multicolumn{7}{|c|}{ t-test for Equality of Means } \\
\hline T & Sig. (2-tailed) & Mean Difference & Std. Error Difference & \multicolumn{2}{|c|}{$\begin{array}{c}95 \% \text { Confidence Interval of the } \\
\text { Difference }\end{array}$} \\
\hline & & & & Lower & Upper \\
\hline 1.927 & 0.091 & 0.158 & 0.0820 & -0.032 & 0.348 \\
\hline
\end{tabular}

Source: Survey conducted by the researcher.

In the Tables 6 and 6 (A), $\mathrm{H}_{0}$ is two sided, a two tailed $\mathrm{t}-$ test applied for independent samples is used for determining the rejection region at 5\% significance level. At $95 \%$ confidence interval of the difference, the lower region is -0.032 and upper region is 0.348 with degrees of freedom 7.809 as equal variances have not been assumed. If $\mathrm{P}$ value $<-0.032$ or $>0.348$, the null hypothesis will be rejected.

Since the $\mathrm{P}$ value is 0.091 which falls in the acceptance region and thus, the null hypothesis will be accepted and it may be concluded that there is no significant difference between the Corporate Governance Policies of Public Sector Banks and Private Sector Banks in India.

2. $\mathbf{H}_{\mathbf{0}}$ : There is no significant difference between the Corporate Governance Policies of Old Private Sector Banks and New Private Sector Banks in India.

$\mathbf{H}_{1}$ : There is significant difference between the Corporate Governance Policies of Old Private Sector Banks and New Private Sector Banks in India.

This hypothesis has been tested and the results are given in Tables 7 and 7(A). 
Table 7: - Corporate Governance Policies

\begin{tabular}{|c|c|c|c|c|c|c|c|}
\hline & \multirow[b]{2}{*}{ Elements } & \multicolumn{2}{|c|}{$\begin{array}{l}\text { Old Private } \\
\text { Sector Banks } \\
(\mathrm{N}=\mathbf{0 8})\end{array}$} & \multicolumn{2}{|c|}{$\begin{array}{l}\text { New Private } \\
\text { Sector Banks } \\
(\mathrm{N}=05)\end{array}$} & \multirow[t]{2}{*}{ P- Value } & \multirow[t]{2}{*}{ T - Value } \\
\hline S. No & & Mean & $\begin{array}{l}\text { St. } \\
\text { Dev. }\end{array}$ & Mean & St. Dev. & & \\
\hline 1 & $\begin{array}{l}\text { Reasons for written code of } \\
\text { conduct }\end{array}$ & 4.292 & 0.719 & 4.600 & 0.548 & 0.018 & -7.400 \\
\hline 2 & Availability of C.G. Policies & 4.583 & 0.474 & 4.533 & 0.548 & 0.782 & 0.304 \\
\hline 3 & $\begin{array}{l}\text { Distribution of Related } \\
\text { Material to Concerned Parties }\end{array}$ & 4.250 & 0.976 & 4.400 & 0.692 & 0.687 & -0.469 \\
\hline 4 & Issues in Code of Conduct & 4.525 & 0.776 & 4.520 & 0.585 & 0.973 & 0.035 \\
\hline 5 & $\begin{array}{l}\text { Other components of } \\
\text { Corporate Governance }\end{array}$ & 4.656 & 0.619 & 4.500 & 0.721 & 0.544 & 0.673 \\
\hline & Total : - (Average) & 4.461 & 0.180 & 4.511 & 0.072 & 0.593 & -0.569 \\
\hline
\end{tabular}

Source: Survey conducted by the researcher.

\begin{tabular}{|c|l|l|l|l|l|}
\hline \multicolumn{5}{|c|}{ Table 7(A): - Independent Samples Test } \\
\hline \hline \multicolumn{5}{|c|}{ t-test for Equality of Means } \\
\hline \hline $\mathrm{T}$ & Sig. (2-tailed) & Mean Difference & $\begin{array}{c}\text { Std. Error } \\
\text { Difference }\end{array}$ & \multicolumn{2}{c|}{$\begin{array}{c}\text { 95\% Confidence Interval of the } \\
\text { Difference }\end{array}$} \\
\hline \hline & & & & Lower & Upper \\
\hline \hline-0.569 & 0.593 & -0.049 & 0.087 & -0.270 & 0.171 \\
\hline
\end{tabular}

Source: Survey conducted by the researcher.

As per the Table 7 and Table 7 (A), $\mathrm{H}_{0}$ is two sided, hence, a two tailed $\mathrm{t}$ - test applied for independent samples is used for determining the rejection region at 5\% significance level. At $95 \%$ confidence interval of the difference, the lower region is -0.270 and upper region is 0.171 with degrees of freedom 5.25 as equal variances have not been assumed. If $\mathrm{P}$ value $<-0.270$ or $>0.171$, the null hypothesis will be rejected.

Since the $\mathrm{P}$ value is 0.593 which does not fall in the acceptance region and thus, the null hypothesis will be rejected and it may be concluded that there is significant difference in the Corporate Governance Policies between the Old Private Sector Banks and New Private Sector Banks in India.

\section{Conclusion}

Banking system plays a very important role in the economic life of the nation. The health of the economy is closely related to the soundness of its banking is now an essential part of our economic system. Modern trade and commerce would almost be impossible without the availability of suitable banking services. The Indian banking system is among the healthier performers in the world. In the liberalized economic environment and integration of the country, in to world market the corporate sector in India at present cannot ignore the importance of Corporate Governance. Corporate Governance is now an issue and important factor that can be used as tool to maximize wealth of shareholders of a corporate. Corporate Governance aims are the Vision, Values and Visibility. Since banks are important players in the Indian financial system, special focus on the Corporate Governance in the banking sector becomes critical. Dr. Y. V. Reddy, the former governor of RBI, has rightly said, "Corporate Governance is the only royal road to the portal of corporate success and there is no 
short cut to achieve the same. A short cut can lead to short circuiting, which can cause colossal loss to the banks concerned".

Corporate Governance Policies of each company have been evolved and adopted from time to time in view of the legal and cultural scenarios in which these companies are operating. In India, the Corporate Governance Policies are framed in the light of Companies Act and Clause 49 of SEBI's listing agreement. Sound Corporate Governance Policies are important to the creation of shareholders value and maintaining the confidence of customers and investors alike. After analyzing the Corporate Governance policies of the 33 Indian commercial banks, it has been found that there is no significant difference between the corporate Governance Policies of Public Sector Banks and Private Sector banks; in contrary to this, there exists a significant difference between the Old Private Sector Banks and New Private Sector Banks in India. In today's dynamic corporate world Commercial Banks in India needs to adopt and strengthen the corporate governance policies not only to boost and enhance pecuniary benefits but as a path to gaining public image, thus recognised by the society in which the bank operates as socially receptive commercial bank(s) which may augment the banks operations and survival.

\section{Acknowledgements}

We are grateful to the executive and non-Executive directors, managers and other officers of the Indian Commercial Banks, who contributed to the development of the study.

\section{References}

[1] Romero, Alberto, G. (2003), The need for Corporate Governance in Averting banking Crises -Lessons from the Banco Latino Crisis, speech, KPMG Banking Seminar in the Dominican Republic, (2003).

[2] Vasile, Cocris, and Maria Cristina Ungureanu (2007), Why are Banks Special? An Approach from the Corporate Governance Perspective, Scientific Annals - Al.I.Cuza University of Iasi, Economics Series,55-66, Available at SSRN: http://ssrn.com/abstract=1090291, accessed on 7 Nov. 2013

[3] Ross, Levine, The Corporate Governance of Banks: A Concise Discussion of Concepts and Evidence, World Bank Policy Research Working Paper No. 3404, 2004, Available at SSRN: http://ssrn.com/abstract=625281, accessed 8 Nov. 2013.

[4] T.G. Arun, and J.D. Turner, Corporate Governance of Banks in Developing Economies: Concepts and Issues, Corporate Governance: An International Review, 12 (3), 371-377, 2004, Available at SSRN: http://ssrn.com/abstract = 557319, surfed on 7th Nov. 2013.

[5] Salim Chahine, and Assem Safieddine, Is corporate governance different for the Lebanese banking system? journal of Management and governance or DOI: 10.1007/s10997-009-9096-7, 2009

[6] Asian Roundtable on Corporate Governance (2006), Policy Brief on Corporate Governance of Banks in Asia, www.oecd.org, accessed on 10 November, 2013

[7] A.P. Pati, Does Corporate Governance Matter in Indian Banking? Policy Implication on the Performance, (Indian Institute of Capital Markets) 9th Capital Markets Conference Paper, 2006. Available at SSRN: http://ssrn.com/abstract $=877810$, accessed on 7 November 2013

[8] Clause 49 of the SEBI's Listing Agreement, http://www.sebi.gov.in/circulars/2004/cfdcir0104, accessed on 7 November 2013. 